\title{
Determinants of Capital Structure: A Case of Listed Energy Sector Companies in Pakistan
}

\author{
Kashif Ghani \\ Syed Husnain Bukhari
}

\begin{abstract}
This study is aimed at determining the capital structure of listed energy sector companies in Pakistan, with a view to finding out the impact of four variables, i.e. tangibility, size, growth and profitability of the firms on their leverage. The sample included data for 20 companies for the period spanning 2004 to 2008. Our results show that all these factors affect the leverage of a firm in some degree. We found that tangibility and size have positive association with leverage which supports the predictions of Static Tradeoff Theory. On the other hand, profitability was found to have negative relationship with a firm's level of debt, a finding that supports the viewpoint presented by Pecking Order Theory. Growth had positive relationship with leverage thus supporting the simple version of Pecking Order Theory.
\end{abstract}

Keywords: Capital Structure, Leverage, Static Tradeoff Theory, Pecking Order Theory.

\section{Introduction}

\subsection{Background and overview}

The capital structure of any firm comprises of two basic components, i.e. equity and debt. How a firm decides to use a combination of debt and equity to design its capital structure depends on various considerations that managers take into account. Choice of the right capital structure is important because the organization wants to maximize its returns to various stakeholders and at the same time desires to be competitive in its external environment.

\subsection{Problem statement and purpose of study}

The research problem involves the need to determine which factors are more influential in determining the level of leverage of listed companies in the energy sector of Pakistan. We intend to find out whether a firm's tangibility of assets, size, growth and profitability significantly affect its leverage and what is the direction of this influence (i.e. positive or negative association), and to find out which of the capital structure theories better explains the capital structure of these firms.

\section{Literature Review and Theoretical Framework}

\subsection{Theories of Capital Structure}

Various theories of capital structure have been presented which attempt to explain the factors that determine the capital structure of firms. Three major theories having relevance to our study are discussed below:

Kashif Ghani is an MS Student at SZABIST, Karachi, kashif.ghani@live.com

Syed Husnain Bukhari is Joint Director, Statistics \& Data Warehouse Department at State Bank of Pakistan, Karachi. 


\section{i. Static Tradeoff Theory (STT)}

The static tradeoff theory focuses on the advantages and disadvantages of issuing debt versus equity. According to this theory, firms target an optimal debt ratio believing that such ratio will maximize the value of the firm. The optimal point is achieved when the marginal benefit of issuing debt equals the increase in the costs associated with issuing more debt (Myers, 1977).

\section{ii. $\quad$ Pecking Order Theory (POT)}

The other major theory found in corporate finance literature is the pecking order theory. According to this theory, firms prefer to finance their investments with internally generated funds as opposed to external financing and this very fact determines a firm's capital structure. When external financing is required, managers tend to prefer debt financing over equity.

\section{iii. Agency Theory}

The third theory of capital structure is the Agency Theory. This theory states that an optimum capital structure results from minimization of the costs arising from conflicts between shareholders and debt-holders (Buferna et al., 2005).

\subsection{Summary of Literature Review}

A large body of literature is found on various aspects of capital structure choice decisions and the mechanics involved. Some of these studies are discussed below:

\section{i. Capital Structure Choice-Research in the Developed World}

Myers and Majluf (1984) in their famous study contended that when managers possess superior information and managers choose to finance their investment through issue of stock, the price of company's stock is likely to fall, ceteris paribus. Titman and Wessels (1988) analyzed the explaining power of some of the theories of optimal capital structure. They used the linear structural modeling in this study and found that companies with unique products have relatively low debt ratios. They also found that smaller firms generally use more short-term loans than larger firms. They found no evidence that debt ratios are related with a firm's expected growth, tax shields, volatility or tangibility of assets. However, they did find evidence that profitability of the firm was associated with debt, as more profitable firms tended to have less debt relative to market value of equity.

Harris and Raviv (1990) argued that managers are not willing to forgo power and not willing to provide such information to shareholders that would lead to reduction in the control the managers have on the affairs of the firm. Chiarella et al. (1991) found that the relationship between leverage and profitability was negative; supporting the idea that firms prefer using internal sources to finance their assets as opposed to external sources. Interestingly, the researchers did not find support for the relationship between growth opportunities and collateral value, suggesting that this factor did not play a significant role in guiding managers' capital structure decisions. Rajan and Zingales (1995) studied the capital structure decisions in a sample of public firms in G-7 
countries. They found that tangibility was positively correlated with leverage across all countries. Size was found to be positively correlated with leverage in all countries except Germany. The researchers also concluded that variables that were found to be correlated with debt-ratios in United States were also found to be correlated in other G-7 countries. Chen et al. (1998) studied the capital structure decisions in the light of various theories using a sample of Dutch firms. They concluded that for Dutch firms, agency cost factors and corporate control factors are less relevant in explaining capital structure choice. Bancel and Mittoo (2002) studied capital structure in a selection of European firms. However, their study was unique in the sense that they surveyed financial managers in European firms to unearth the link between the theory and practice of finance with reference to capital structure decisions.

\section{ii. Capital Structure Research in Developing countries}

Booth et al. (2001) analyzed capital structure decisions across 10 developing countries in their study and found that capital structure decisions in developing countries are taken in a similar manner as in developed countries. Buferna et al. (2005) studied a set of Libyan firms to understand the determinants of capital structure with an additional aim of trying to understand the impact of lack of a developed secondary market. They contended that agency costs are linked with the absence of a secondary market as the shareholders who are unable to sell-off their shares in the market may try to influence the firms to take actions deemed appropriate by those shareholders.

\section{iii. Capital Structure Research in Pakistan}

Shah and Hijazi (2004) studied the capital structure of listed firms in Pakistan (other than financial institutions). They found that asset tangibility was positively related with leverage (though not significantly); size was positively related, while profitability and growth were negatively related with level of debt.

Tariq and Hijazi (2006) studied the capital structure of listed cement companies in Pakistan. Their aim was to study the unique attributes of this sector and how its capital structure decisions differ from other listed firms. They found that size and profitability were negatively related while tangibility and growth were positively related with leverage.

\section{Data and Methodology}

\subsection{Data Sources}

a. Data for this study were obtained from 'Balance Sheet Analysis of Joint Stock Companies' compiled by State Bank of Pakistan for the period 2004-2008. As per classification of Karachi Stock Exchange, the listed energy sector includes Oil \& Gas Marketing Companies, Oil \& Gas Exploration Companies, Power Generation Companies and refineries. Initially, we selected all companies in the energy sector. 
However, after scrutiny the companies with incomplete data were removed from the sample. Our final sample consisted of 20 companies.

\subsection{Explanation of variables used in the study}

The following section presents the explanation of the variables used in this study and how these variables are measured.

\section{i. Leverage}

Leverage is the dependent variable in this study, defined as the percentage of assets financed by debt. We use book value of total liabilities divided by total assets as a measure of leverage because most firms in Pakistan rely on short-term debt to meet their capital requirements as the average firm size is small and banks are more inclined to lend for short-term than for long-term.

\section{ii. Tangibility}

It is believed that a firm with large amount of fixed assets (i.e. greater tangibility of assets) finds it easier to raise debt due to the collateral value of its assets as compared to a firm with lesser tangible assets. Thus firms with large amount of fixed assets are expected to have higher leverage due to their ability to raise large amount of debt at relatively cheaper rates (Sevil et al., 2005).

We measure tangibility of assets as a ratio of fixed assets (net of depreciation) to total assets. Thus the first hypothesis for this study is:

Hypothesis 1: "a firm with higher tangibility of assets will have higher leverage"

\section{iii. Size}

Static Tradeoff Theory postulates that larger firms are likely to have higher amount of debt due to relatively lower risk of bankruptcy. Thus there should be a positive relationship between size of the firm and leverage. We measure size of the firm by natural Logarithm of sales as done, among others, by Chen et al. (1998) and Booth et al. (2001). This gives us our next hypothesis:

Hypothesis 2: "there is positive relationship between size of a firm and its leverage"

\section{iv. Growth}

Abor (2008) mentions that growing firms require funds to finance the growing operations and internally generating funds may not be sufficient to finance that growth, thus growing businesses resort to heavy leverage. We measure growth as the annual percentage change in total assets. Our third hypothesis is:

Hypothesis 3: "firms with higher rate of growth are expected to have higher degree of leverage"

\section{vi. Profitability}

Profitability is generally expected to be negatively related to leverage of the firm. There is contradictory view given by static tradeoff theory and pecking order theory in relation to the impact of profitability on firm leverage. 
The tradeoff theory expects a positive relation between profitability and leverage while Pecking order theory expects negative relationship between the two variables.

We measure profitability as earning before taxes divided by firm's total assets. So our next hypothesis is:

Hypothesis 4: "firms with higher profitability will have lower leverage"

\subsection{Regression Model}

We have used pooled data analysis for this study since our data are panel data. Data on our dependent variable (leverage) and four independent variables were obtained and proxies were used to define those variables. Using the pooled regression model, we obtained the association each of our independent variables has on leverage. The model used for this study is given below:

$$
L=\beta_{1}(T)+\beta_{2}(S)+\beta_{3}(G)+\beta_{4}(P)+\varepsilon
$$

Where

$$
\begin{aligned}
& L=\text { Leverage } \\
& T=\text { Tangibility of assets } \\
& S=\text { Size of the firm } \\
& G=\text { Growth } \\
& P=\text { Profitability } \\
& \varepsilon=\text { the error term }
\end{aligned}
$$

\begin{tabular}{|c|c|c|c|c|c|}
\hline & Leverage & Tangibility & Size & Growth & Profitability \\
\hline Mean & 0.563 & 0.458 & 4.080 & 0.155 & 0.109 \\
\hline Median & 0.631 & 0.472 & 4.428 & 0.144 & 0.066 \\
\hline Maximum & 0.990 & 0.939 & 5.695 & 0.701 & 0.554 \\
\hline Minimum & 0.014 & 0.041 & 0.857 & -0.354 & -0.212 \\
\hline Std. Dev. & 0.246 & 0.249 & 0.995 & 0.191 & 0.164 \\
\hline Observations (N) & 100 & 100 & 100 & 100 & 100 \\
\hline
\end{tabular}

\section{Empirical analysis}

\subsection{Descriptive Statistics}

The following table summarizes the descriptive statistics for the data used in our study. It may be noticed that minimum leverage for any firm was 0.014 (1.4\%) while maximum was 0.99 (99\%). Mean leverage was $56.3 \%$.

\subsection{Regression Analysis Results}

The following table presents the results of our regression analysis. $R$-squared $\left(R^{2}\right)$ has a value of 0.886 which means that our independent variables (tangibility, growth, size and profitability) explain about $88 \%$ of the 
variation in our dependent variable (leverage). Durbin Watson statistic is close to 2.00 which shows that there is no problem of autocorrelation.

\begin{tabular}{|l|r|l|r|}
\hline R-squared & 0.886 & Mean dependent var & 0.563 \\
\hline Adjusted R-squared & 0.869 & S.D. dependent var & 0.246 \\
\hline S.E. of regression & 0.089 & Akaike info criterion & -1.874 \\
\hline Sum squared resid & 0.679 & Schwarz criterion & -1.509 \\
\hline Log likelihood & 107.708 & Durbin-Watson stat & 2.020 \\
\hline
\end{tabular}

\section{Regression Coefficients and their significance}

The following table shows coefficients of our regression analysis. It may be noticed that coefficients of all independent variables (other than growth) were found to be significant at $1 \%$ level, while growth was significant at $5 \%$ level.

\begin{tabular}{|c|r|r|r|r|}
\hline Variable & Coefficient & Std Error & t-Statistic & Probability \\
\hline Tangibility & 0.268128 & 0.064496 & 4.157302 & 0.0001 \\
\hline Size & 0.136057 & 0.009180 & 14.82100 & 0.0000 \\
\hline Growth & 0.121275 & 0.055101 & 2.200961 & 0.0304 \\
\hline Profitability & -0.467314 & 0.126065 & -3.706937 & 0.0004 \\
\hline
\end{tabular}

We can see that tangibility is significant at $1 \%$ significance level $\left(B_{1}=0.268\right)$ and has positive association with leverage. This is as expected because availability of tangible assets makes it easier for firms to obtain loans from banks and other lenders.

Size was found to be positively associated with leverage and was significant at $1 \%$ level $\left(B_{2}=0.136\right)$. Our third independent variable - growth was found to be positively related with leverage. It was significant at $5 \%$ level $\left(B_{3}=0.121\right)$. Our final independent variable - Profitability was found to be negatively associated with leverage at significance level of $1 \%\left(B_{4}=0.467\right)$.

\section{Conclusion and Recommendations for further research}

The table below summarizes the finding of our study in the light of Static Tradeoff and Pecking Order Theories. Our findings in relation to the impact of Tangibility and Size on leverage were found to be in conformance with the static tradeoff theory. The impact of profitability was found to be in accordance with the prediction of Pecking Order Theory. Our finding with relation to the impact of Growth was found to be in conformance with the simple version of Pecking Order Theory (which states that growth firms would finance the expanding operations by incurring more debt).

\begin{tabular}{|l|l|l|l|l|}
\hline Variable & Measured by & $\begin{array}{l}\text { Expected } \\
\text { Relationship in Static } \\
\text { Tradeoff Theory }\end{array}$ & $\begin{array}{l}\text { Expected } \\
\text { Relationship in } \\
\text { Pecking Order } \\
\text { Theory }\end{array}$ & $\begin{array}{l}\text { Observed } \\
\text { Relationship (in } \\
\text { this study) }\end{array}$ \\
\hline Tangibility & $\begin{array}{l}\text { Fixed Assets (net)/ } \\
\text { Total Assets }\end{array}$ & Positive & Negative & Positive \\
\hline Size & Log of sales & Positive & Negative & Positive \\
\hline Growth & Earnings before taxes/ & Negative & Positive/ Negative & Positive \\
\hline
\end{tabular}




\begin{tabular}{|c|c|c|c|c|}
\hline & total assets & & & \\
\hline Profitability & $\begin{array}{l}\text { Percentage change in } \\
\text { total assets over the } \\
\text { previous year }\end{array}$ & Positive & Negative & Negative \\
\hline
\end{tabular}

* Simple and Complex version of Pecking Order Theory

Thus our results show that predictive capability of these capital structure theories is rather mixed, as no single theory completely explains the behavior of financial decision makers of these firms. We may conclude that in Pakistan, power sector firms with more tangible assets use greater debt which may be due to the collateral value of their assets and ease of obtaining financing. Firms with more tangible assets find it easier to obtain financing as lenders would be more willing to lend against the security of fixed assets. It was also observed that for Pakistani energy sector firms, size was found to be positively associated with leverage suggesting that larger firms tend to use higher leverage.

The reasons could be lower bankruptcy risks in larger firms, more diversified portfolio and ease of obtaining financing. Our third independent variable, Growth, was found to be positively associated with leverage which supports the simple version of pecking order theory. Our results do not support the prediction of static tradeoff theory that growing firms will tend to have less leverage as they would find it difficult to invest sub-optimally. Our fourth variable, profitability, was found to be negatively associated with leverage supporting the view of Pecking Order Theory that profitable firms tend to have less leverage due to availability of internally generated funds.

\section{Suggested areas for further research}

The following areas may be considered for future research:

- Using different measures of leverage (e.g. short-term and long-term debt)

- Incorporating both book value and market value of debt

- Including a larger sample of companies and doing intra-sector comparisons

- Differentiating between different ownership structures 


\section{References}

Bancel, F. and Mitto, U. (2002), 'The Determinants of Capital Structure Choice: A Survey of European Firms', Available at SSRN: papers.ssrn.com/sol3/papers.cfm?abstract_id=299172

Booth, L., Aivazian, V., Demirguc-Kunt, A. and V. Maksmivoc (2001), 'Capital structures in developing countries', Journal of Finance, Vol. 56, pp. 87-130.

Buferna, F., Bangassa, K. and Hodgkinson, L. (2005), 'Determinants of Capital Structure - Evidence from Libya', University of Liverpool Research Paper Series No.2005/08.

Chen, L., Lensink, R. and Sterken, E. (1998), 'The Determinants of Capital Structure: Evidence from Dutch Panel Data', European Economic Association Annual Congress, Berlin, September 2-5, 1998.

Chiarella, C., Pham, T., Sim, A.B, and Tan, M. (1991), 'Determinants of Corporate Capital Structure: Australian Evidence' "University of Technology, Sydney - School of Finance and Economics Working Paper"

Harris, M. and A. Raviv, (1990) Capital structure and the informational role of debt, Journal of Finance Vol. 45, pp. 321-349

Hijazi, T. and Tariq, Y. (2006), 'Determinants of Capital Structure: A Case for the Pakistani Cement Industry', The Lahore Journal of Economics, Vol. 11:1, (Summer 2006), pp. 63-80.

Modigliani, F. and Miller, M., (1958), 'The Cost of Capital, Corporation Finance and the Theory of Investment', The American Economic Review, Vol. 48, pp. 433-443.

Myers, S., and N. Majluf, (1984), 'Corporate Financing and Investment Decisions When Firms Have Information Investors Do Not Have', Journal of Financial Economics, Vol. 13, pp. 187-222.

Myers, S.C., (1977), 'Determinants of Corporate Borrowing', Journal of Financial Economics, Vol. 5. pp. 147-175

Rajan, R. and Zingales, L., (1995), 'What Do We Know about Capital Structure? Some Evidence from International Data', The Journal of Finance, Vol. 50. pp. 1421-1460.

Sevil, G., Sayılır, O. and Yıldırım, S. (2005), ‘Determinants of Capital Structure: Evidence from Turkish Manufacturing Firms', http://home.anadolu.edu.tr/ gsevil/capital.pdf

Shah, A. and Hijazi, T. (2004), 'The Determinants of Capital Structure of Stock Exchange-listed Non-financial Firms in Pakistan', The Pakistan Development Review, Vol. 43:4, Part II, pp. 605-618. 
State Bank of Pakistan, 'Balance Sheet Analysis of Joint Stock Companies Listed on The Karachi Stock Exchange'- 2008.

Titman, S. and Wessels, R., (1988), 'The Determinants of Capital Structure Choice', The Journal of Finance, Vol. 43, No.1, pp. 1-19. 